\title{
Review
}

\section{Autolysis of thermophilic lactobacilli and dairy propionibacteria: a review}

\author{
S Lortal, R Lemée, F Valence \\ Laboratoire de Recherches de Technologie Laitière, INRA, 65, rue de St-Brieuc, 35042 Rennes Cedex, France
}

Summary - The peptidases and esterases of thermophilic lactobacilli and dairy propionibacteria, which are known to participate in the ripening of Swiss-type cheeses, are mainly intracellular. Their release in cheeses requires a necessary autolytic event. The aim of this review is to summarize the current knowledge on autolysis of cheese-related thermophilic lactobacilli and dairy propionibacteria, focussing in particular on the preliminary demonstration of autolysis in cheese-like substrates, the strain-dependence of autolysis, the biochemical characterization of the autolysins involved, and the effect of environmental parameters such as $\mathrm{pH}$, temperature and ionic strength on the maximal extent of autolysis. Further issues in this research area will also be discussed.

autolysis / Lactobacillus / Propionibacterium

Résumé - Autolyse des lactobacilles et des bactéries propioniques laitières. De nombreuses peptidases et esterases de lactobacilles thermophiles et des bactéries propioniques laitières sont connues pour participer à l'affinage des fromages à pâte pressée cuite. Ces enzymes étant principalement intracellulaires, leur participation dépend de leur libération dans la pâte fromagère par le phénomène d'autolyse bactérienne. L'objectif de cette revue est de faire le point des connaissances sur l'autolyse des lactobacilles thermophiles et des propionibactéries, en traitant notamment les aspects suivants : la démonstration de l'autolyse dans le fromage ou dans des substrats fromagers, le caractère souchedépendant de l'aptitude à l'autolyse, la caractérisation biochimique des autolysines impliquées, et l'effet des paramètres tels que $\mathrm{pH}$, température et force ionique sur l'ampleur de l'autolyse. Les recherches futures dans ce domaine seront enfin discutées.

autolyse / Lactobacillus / Propionibacterium

Oral communication at the IDF Symposium 'Ripening and Quality of Cheeses', Besançon, France, February 26-28, 1996. 


\section{INTRODUCTION}

It has been well known for a long time that milk casein proteolysis is a key factor in the ripening of cheese, and that lactic acid bacteria play a major role in this proteolytic event. Recently, the intracellular location of seemingly all lactococcal peptidases has been clearly established in the literature (Monnet et al, 1993; Tan et al, 1993). This has led to the question of how these peptidases are released in cheeses, and to a rapidly growing interest over recent years in the autolysis phenomenon in lactic acid bacteria (Crow et al, 1995a,b; Chapot-Chartier, 1996). Bacterial autolysis could be defined as a spontaneous cell breakdown phenomenon due to the hydrolysis of the peptidoglycan network by cell wall located enzymes, the so-called 'autolysins' (Rogers et al, 1980; Shockman and Höltje, 1994). In general, it occurs spontaneously after a stationary phase.

Regarding lactic acid bacteria, the most relevant data concern the autolysis of lactococci, which has been demonstrated in Cheddar and St-Paulin cheeses (Law et al, 1974; Crow et al, 1993; 1995 a,b; Chapot-Chartier et al, 1994; Wilkinson, 1994 a,b) and which appeared to be correlated with a higher proteolysis (a four- to seven-fold increase in free amino acids was observed). In addition, the major $46 \mathrm{kDa}$ autolysin of Lactococcus lactis has been cloned and sequenced (Buist et al, 1995).

Thermophilic lactobacilli (Lactobacillus helveticus; Lactobacillus delbrueckii subsp lactis) and dairy propionibacteria (mainly Propionibacterium freudenreichii) are used together in Swiss-type cheese making (Langsrud and Reinbold, 1973; Accolas et al, 1978). Moreover, dairy propionibacteria seem to be used to a greater extent in semi-hard cheeses (eg, in Leerdammer, Madrigal, Petit Rippoz, Dorebel, or Fol Epi, where $10^{6}-10^{8} \mathrm{cfu} / \mathrm{g}$ of propionibacteria are regularly enumerated; Madec, pers commun). $L$ helveticus is also highly important in the Italian cheese Grana Padano (Torriani et al, 1994), and other thermophilic species such as $L$ acidophilus and $L$ delbrueckii subsp bulgari- cus are involved in the obtention of various fermented milks. The enzymatic activities of thermophilic lactobacilli and dairy propionibacteria which could be of some importance for the proteolysis and/or lipolysis of milk components have been extensively described in the literature (Umanskii et al, 1974, 1979; El Soda et al, 1986; Bouton et al, 1993, 1994; Dupuis and Boyaval, 1993; Dupuis et al, 1993; Lambrechts, 1993; for a review, see Pritchard and Coolbear, 1993; Langsrud et al, 1995). Characterization of the genes involved in proteolysis, despite being far less developed than in lactococci, continues to increase (Nowakowski et al, 1993; Klein et al, 1994; Varmanen et al, 1994; Yüksel and Steele, 1996). For many of the peptidases and esterases described, the intracellular location has been demonstrated or highly suspected, again leading to the question of these species' potential autolysis in cheese. Indeed, the variety and height of activity of the peptidases described in lactobacilli (Sasaki et al, 1995) as well as the rather unusual specificities detected in dairy propionibacteria (some peptidases are able to liberate significantly aromatic amino acids like phenylalanine (Dupuis, 1994) and proline (Langsrud et al, 1995) support the idea that through autolysis these species can influence the final flavour of several kinds of cheese.

The aim of this review is to highlight the data reported in the literature on the autolysis of thermophilic lactobacilli and dairy propionibacteria in cheeses as well as in buffered solutions. The recent results on the autolysins involved will be particularly examined.

\section{AUTOLYSIS IN CHEESE OR CHEESE-LIKE SUBSTRATES}

In cheese where they constitute the principal starters, do thermophilic lactobacilli and dairy propionibacteria lyse spontaneously? If so, does this autolysis influence proteolysis, as has been described for lactococci? There is no answer to these questions in the literature on dairy propionibacteria except in the work of Langsrud et 
al (1977, 1978). These authors observed a correlation between the autolysis of propionibacteria in milk or modified milk (with various nitrogen substrates) and the production of free proline.

For thermophilic lactobacilli, drastic viability losses have frequently been noted after the acidification step in many Swiss-type cheeses (Accolas et al, 1978). This has recently been confirmed in Emmental (Thierry, pers commun) and Comté-type cheeses (Demarigny, pers commun). On the other hand, Prost and Chamba (1994) have suggested to take into account the aminopeptidase activity of $L$ helveticus for an improved flavour development in Emmental cheeses. Since then, the intracellular location of this enzyme has been clearly demonstrated (pepN; Varmanen et al, 1994), and it must be released in order to act and influence proteolysis. These observations support the hypothesis of the autolysis of lactobacilli in cheeses, but do not prove it.

Ohmiya and Sato (1970) were the first to follow the autolysis of $L$ helveticus in technological conditions. The cells harvested in the stationary phase were included in an aseptic rennet curd, which was kept for 63 days at $10^{\circ} \mathrm{C}$. DNA release was observed after 8-10 days, and damaged cells were visualized by electron microscopy (but later, at 63 days of incubation). In 1975, Bie and Sjöström (1975a,b) studied the autolysis of a mesophilic starter and of $L$ helveticus (eventually thermo-shocked) in casein liquid substrates and in semi-hard cheeses. They improved the quantification of free DNA (taking in account its degradation after release) and were the first to indicate that the extent of autolysis differed between two strains of $L$ helveticus (CNRZ 303/CNRZ 32). Lastly, they demonstrated that the addition of thermo-shocked $L$ helveticus had a significant effect on the proteolysis of the experimental cheeses. A similar increase in the extent of proteolysis was also achieved by adding 'attenuated' $L$ helveticus cells (by heating, freezing, lysozyme treatment, etc) to various cheeses like St Paulin, Egyptian Ras, Feta, Gouda, and reduced-fat Cheddar (El Soda, 1993; Wilkin- son, 1993; Johnson et al, 1995). Nevertheless, the fact that the attenuation treatment has possibly improved the subsequent autolysis of $L$ helveticus in cheeses remains to be demonstrated. Lastly, damaged cells of $L$ helveticus have been visualized in Grana by scanning electron microscopy in the days following pressing, indicating an early autolysis in that cheese (Bottazzi, 1993).

In our laboratory, we are currently quantifying the autolysis of $L$ helveticus and $P$ freudenreichii in mini Swiss-type cheeses, which is carried out by the Institut Technique du Gruyère. The cheeses are made from thermised and microfiltered milk, as described by Richoux and Kerjean (1995). In our assay, no L delbrueckii subsp lactis were inoculated. The following specific intracellular markers were chosen: lactate dehydrogenase (LDH) and a dipeptidase (pepD) for $L$ helveticus, and methylmalonyl-coenzymeAmutase for $P$ freudenreichii. Their detection in the aqueous cheese extracts at different ripening times is currently being investigated. Preliminary results indicated an extensive autolysis of $L$ helveticus during ripening (unpubl obs).

In conclusion, data supporting the idea of autolysis of thermophilic lactobacilli in cheeses are encouraging, but for the moment are rather sparse and fragmented. Further work necessitates a clear demonstration of the phenomenon via intracellular markers, and an estimation of its impact on the proteolysis of curd.

\section{FACTORS INFLUENCING CELL AUTOLYSIS}

Since the autolysis of whole cells is the consequence of an enzymatic reaction, ie, the hydrolysis of peptidoglycan bonds by autolysins, its rate and extent depend on all the physical and biochemical parameters which, as a general rule, influence enzymatic reactions: $\mathrm{pH}$, temperature, ionic strength, presence of particular cations, etc. These parameters may act on the substrate (accessibility of the peptidoglycan in the cell wall) and/or on the autolysins themselves. 
Insofar as it is also a 'cellular' phenomenon, two additional factors greatly influence the rate and extent of autolysis: i) the strain; indeed, the tendency to autolyse is a strain-dependent feature, and this point is developed below; ii) the physiological state of the cells. The age of the culture as well as its 'history' (occurrence of various stresses, heat treatment, nature and temperature of the growth medium, etc) influence the subsequent autolytic activity. The various factors affecting autolysis have been presented separately in the following paragraphs.

\section{The environmental parameters}

By varying the environmental parameters noted above, it is possible to establish favourable or even optimal conditions for the autolysis of a considered species. For this purpose, the cells are harvested (generally during the exponential growth phase; this requirement is explained below) and transferred into buffered solutions; this constitutes a brutal nutrient starvation as well as a relative osmotic shock. Such a procedure has been shown to efficiently induce the autolysis of numerous gram(-) or gram(+) species like $E$ coli or Bacillus subtilis (Shockman, 1965; Leduc and van Heijenoort, 1980; Leduc et al, 1982). When the objective is the optimization of the parameters, the autolysis is more often followed by the decrease in the optical density at $650 \mathrm{~nm}\left(\mathrm{OD}_{650}\right)$ of the suspension, and sometimes by the increase in proteins or free DNA in the supernatant. This approach has been applied to lactobacilli and dairy propionibacteria by several authors, who have determined favourable conditions for cell autolysis, with slight variations between laboratories. Briefly, these conditions are as follows for $L$ helveticus and $L$ acidophilus: a sodium (or potassium) phosphate (or citrate) buffer (50 to $100 \mathrm{mmol} / \mathrm{L}$; $\mathrm{pH}$ between 5 and 7) at a temperature of between 37 and $45^{\circ} \mathrm{C}$ (Coyette and Ghuysen, 1970b; Coyette and Schockman, 1973; Premi et al, 1973; Ohmiya and Sato, 1975; Lortal et al, 1989, 1991; Fernandez Murga et al, 1994, 1995). For L delbrueckii, parameters have not been optimized. Nevertheless, we can indicate that the autolysis of that species can be readily induced by using a $0.1 \mathrm{~mol} / \mathrm{L}$ potassium phosphate buffer (pH 5.8) at $37^{\circ} \mathrm{C}$ (unpubl obs).

Regarding propionibacteria, a potassium phosphate buffer $(0.1 \mathrm{~mol} / \mathrm{L}$; pH 5.8 to 6.2$)$ or a potassium chloride solution, both at $40^{\circ} \mathrm{C}$, readily induce the autolysis of $P$ freudenreichii (Lemée et al, 1994b). This has been further confirmed by Ostlie et al (1995b), except for the optimal $\mathrm{pH}$; indeed, these authors observed an additional optimal value at $\mathrm{pH} 7.2$.

What could essentially be learned from such studies is the range of environmental variations compatible with the expression of this complex enzymatic autolytic system. The example reported in figure 1 illustrates the influence of $\mathrm{pH}$, temperature and ionic strength on the autolysis of $P$ freudenreichii (unpubl obs).

\section{The age of the culture}

One of the most influential factors on the extent of autolysis obtained in buffer is the state of growth at which the culture is harvested. As a general rule, exponential cells are the most prone to autolysis, and this high autolysin activity during growth supports the idea of their involvement in the division process (hydrolysis of the peptidoglycan to allow the separation of two cells) (Forsberg and Rogers, 1971; Shockman and Höltje, 1994). This influence has been illustrated in figure 2 for three strains of $P$ freudenreichii (unpubl obs). For thermophilic lactobacilli, the highest autolytic activity in buffer was obtained by harvesting the cells at the transition between the exponential and stationary phases. Recently, a second optimal harvesting time was found for $L$ helveticus at the early exponential growth phase (Valence and Lortal, 1995). This obvious variation in autolytic activity during growth is probably one of the most interesting and complex features to be considered about the phenomenon. In any case, there is to our knowledge no definite interpretation in the literature regarding these variations. They could 
be due to a regulation in a number of types of autolysin activity or to an evolution of the cell wall structure and composition. Indeed, it has been described in L acidophilus for example that the proportions of cell wall polymers such as

a

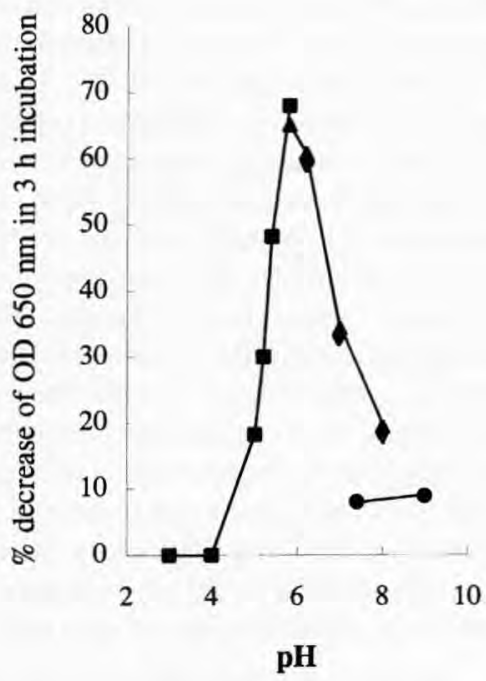

b

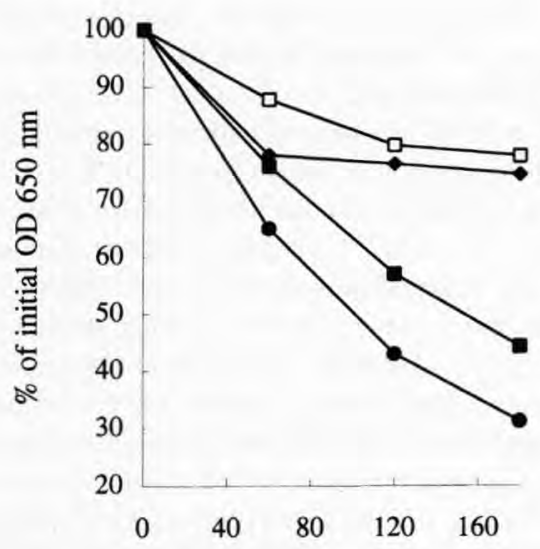

Time (min) teichoic acids and neutral polysaccharides can vary greatly between the exponential and the stationary phases (17\% teichoic acid in the exponential phase compared with $30 \%$ in the stationary phase; Coyette and Ghuysen, 1970a).

Fig 1. Influence of environmental parameters on whole cell autolysis of $P$ freudenreichii CNRZ 725. a. Effect of $\mathrm{pH}$ buffer on autolysis expressed as percentage decrease of $\mathrm{OD}_{650}$ after $3 \mathrm{~h}$ incubation at $40{ }^{\circ} \mathrm{C}$ in sodium citrate $(\mathbf{Q})$, potassium phosphate $(\bullet)$, and Tris- $\mathrm{HCl}(-)$ buffers, all at $0.1 \mathrm{~mol} / \mathrm{L}$. b. Time course of autolysis at various temperatures; (D) $30^{\circ} \mathrm{C}$, ( $\square$ ) $38^{\circ} \mathrm{C},\left(-40^{\circ} \mathrm{C}\right.$ and $\left(-42^{\circ} \mathrm{C}\right.$ in $0.1 \mathrm{~mol} / \mathrm{L}$ potassium phosphate buffer, $\mathrm{pH}$ 5.8. c. Time course of autolysis at various ionic strengths of a $\mathrm{KCl}$ solution at $40^{\circ} \mathrm{C}: \Delta$, $0.001 \mathrm{~mol} / \mathrm{L} ; 0,0.01 \mathrm{~mol} / \mathrm{L} ; \square, 0.05 \mathrm{~mol} / \mathrm{L} ; \mathbf{E}, 0.1$ $\mathrm{mol} / \mathrm{L} ; 0.5 \mathrm{~mol} / \mathrm{L}$. The addition of $0.1 \mathrm{~mol} / \mathrm{L} \mathrm{MgCl}_{2}$ or $\mathrm{CaCl}_{2}$ in $0.1 \mathrm{~mol} / \mathrm{L} \mathrm{KCl}$ significantly inhibited autolysis ( $\square$, dark line).

Influence des paramètres physico-chimiques de l'environnement sur l'autolyse cellulaire de $\mathrm{P}$ freudenreichii $C N R Z$ 725. a. Influence du $\mathrm{pH}$; l'autolyse est exprimée par le pourcentage de réduction de la $D O_{650}$ après trois heures d'incubation à $40{ }^{\circ} \mathrm{C}$ dans les tampons $(0,1 \mathrm{~mol} / \mathrm{L})$ suivants: citrate de sodium $(\boldsymbol{\square})$, phosphate de potassium ( ) et Tris- $\mathrm{HCl}(\bullet)$. b. Influence de la température : autolyse en tampon phosphate de potassium $\left(0,1 \mathrm{~mol} / \mathrm{L} ; \mathrm{pH} 5,8\right.$ à $\square: 30^{\circ} \mathrm{C}, \boldsymbol{\mathbf { Q }}: 38^{\circ} \mathrm{C}$, - : $40{ }^{\circ} \mathrm{C}$, et $\bullet: 42{ }^{\circ} \mathrm{C}$. c. Influence de la force ionique : autolyse en $\mathrm{KCl}$ à $40^{\circ} \mathrm{C}$ à $\Delta: 0,001 \mathrm{~mol} / \mathrm{L}$; - 0,01 mol/L; $\square: 0,05 \mathrm{~mol} / \mathrm{L} ; \boldsymbol{\square}: 0,1 \mathrm{~mol} / \mathrm{L}$; : 0,5 mol/L. L'addition de $\mathrm{MgCl}_{2}$ ou $\mathrm{CaCl}_{2}$ à raison de 0,1 mol/L dans du $\mathrm{KCl} 0,1 \mathrm{~mol} / \mathrm{L}$ inhibe clairement l'autolyse ( $\square$, trait gras).

c

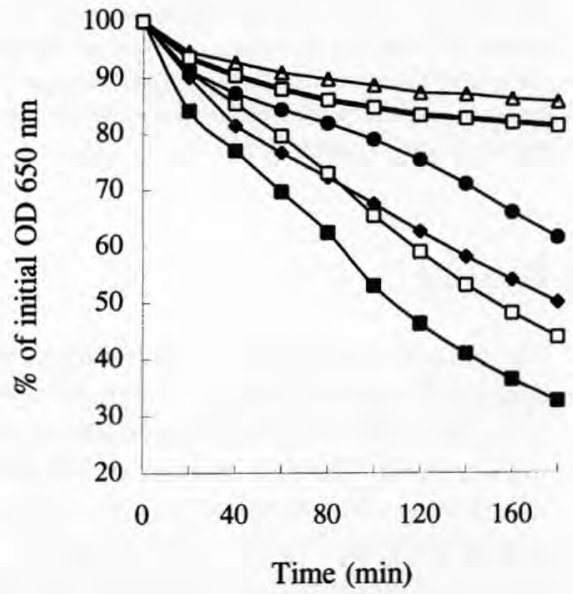




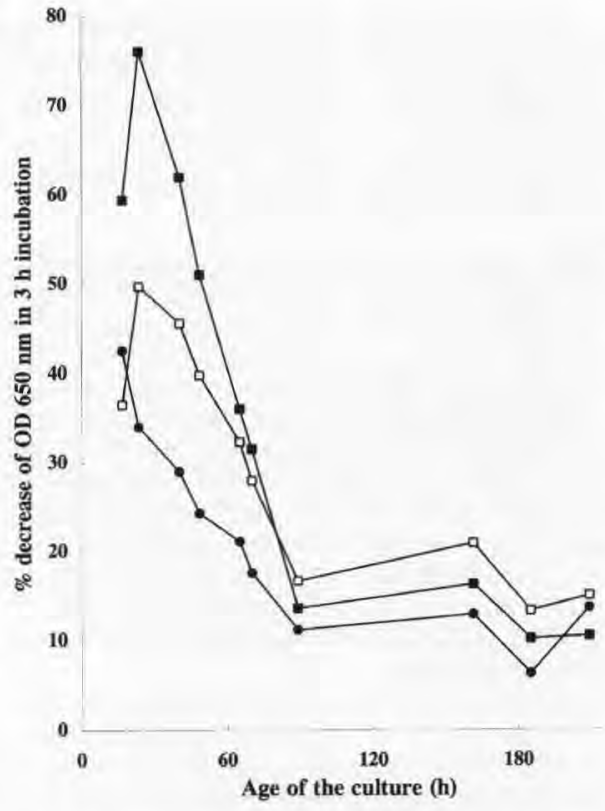

Fig 2. The age of culture at which the cells were harvested influenced the whole cell autolysis. The highest autolysis of $P$ freudenreichii CNRZ 725 (-), CNRZ 726 (Ј), CNRZ 727 ( was obtained with cells harvested in the early exponential growth phase $\left(\mathrm{OD}_{650}\right.$ $<0.5$ ). Autolysis was expressed as the percentage of decrease of $\mathrm{OD}_{650}$ after $3 \mathrm{~h}$ incubation at $40^{\circ} \mathrm{C}$ in $0.1 \mathrm{~mol} / \mathrm{L}$ potassium phosphate buffer, $\mathrm{pH} 5.8$.

Le stade de croissance des cellules lors de leur récolte influence l'autolyse induite en tampon. Pour les trois souches, CNRZ 725 (目), CNRZ 726 (घ) et CNRZ 727 (-), l'autolyse maximale est obtenue avec des cellules récoltées en début de phase exponentielle (culture de 50 heures environ). L'autolyse est exprimée par le pourcentage de réduction de la $D O_{650}$ après 3 heures d'incubation des cellules en tampon phosphate de potassium $0,1 \mathrm{~mol} / \mathrm{L}$ à $\mathrm{pH} 5,8$ et à $40^{\circ} \mathrm{C}$.

\section{The strain}

The tendency to autolyse is a highly straindependent character. There are two main ways to assess the differences between strains regarding autolysis. The first consists of following what happens after maximal growth in broth, in milk or in cheeses. For this, several methods are required: enumeration, determination of the opti- cal density (when possible), electron microscopy observations and detection of intracellular compounds released in the medium through autolysis. In this way, for example, autolytic straindependence has been clearly demonstrated for lactococci in M17 broth (Langsrud et al, 1987) as well as in cheeses (Chapot-Chartier et al, 1994; Wilkinson et al, 1994a,b). Nevertheless, it is not an easy way of comparing the autolytic ability of a large number of strains (in particular for species such as dairy propionibacteria, exhibiting generation times of between five and 15 hours in SLB broth at $30^{\circ} \mathrm{C}$ ). To screen numerous strains, a second method can be used. It consists of inducing autolysis by transferring the cells into a buffer (exhibiting for the species considered the optimal conditions of $\mathrm{pH}$, temperature, etc), as described previously. After a given time (several hours in general), the percentage decrease in $\mathrm{OD}_{650}$ is compared between strains. In order to obtain reproducible and reliable results, all the strains must be harvested as precisely as possible at the same state of growth. This is an important point to bear in mind, because of the strong influence of the culture age on the extent of autolysis measured in buffer, which was examined in the previous paragraph.

The results regarding autolytic strain-dependence in dairy propionibacteria and thermophilic lactobacilli have been summarized in table I and illustrated in figure 3.

For dairy propionibacteria, spontaneous autolysis after maximal growth has been followed in sodium lactate broth at $30^{\circ} \mathrm{C}$ (SLB, also named YEL) by several authors. Depending on the strain, this autolysis varied from 10 to $90 \%$. The complete absence of stationary phase in several strains, ie, autolysis which started just after maximal growth, was a very interesting phenotype which has been further studied by Lemée et al (1994b, 1995). The lactate (carbon source) deprivation at a $\mathrm{pH}$ of 5.8-6.0 in broth seems to be a very efficient inducing factor in the autolysis of $P$ freudenreichii. A similar scale of variations ( 0 to $96 \%$ ) has been observed in buffer by various authors (table I; Lemée et al, 1994a, 1995; Østlie et al, 1995a,b). In other respects, 
Table I. Strain dependence of autolysis.

Souche dépendance de l'autolyse.

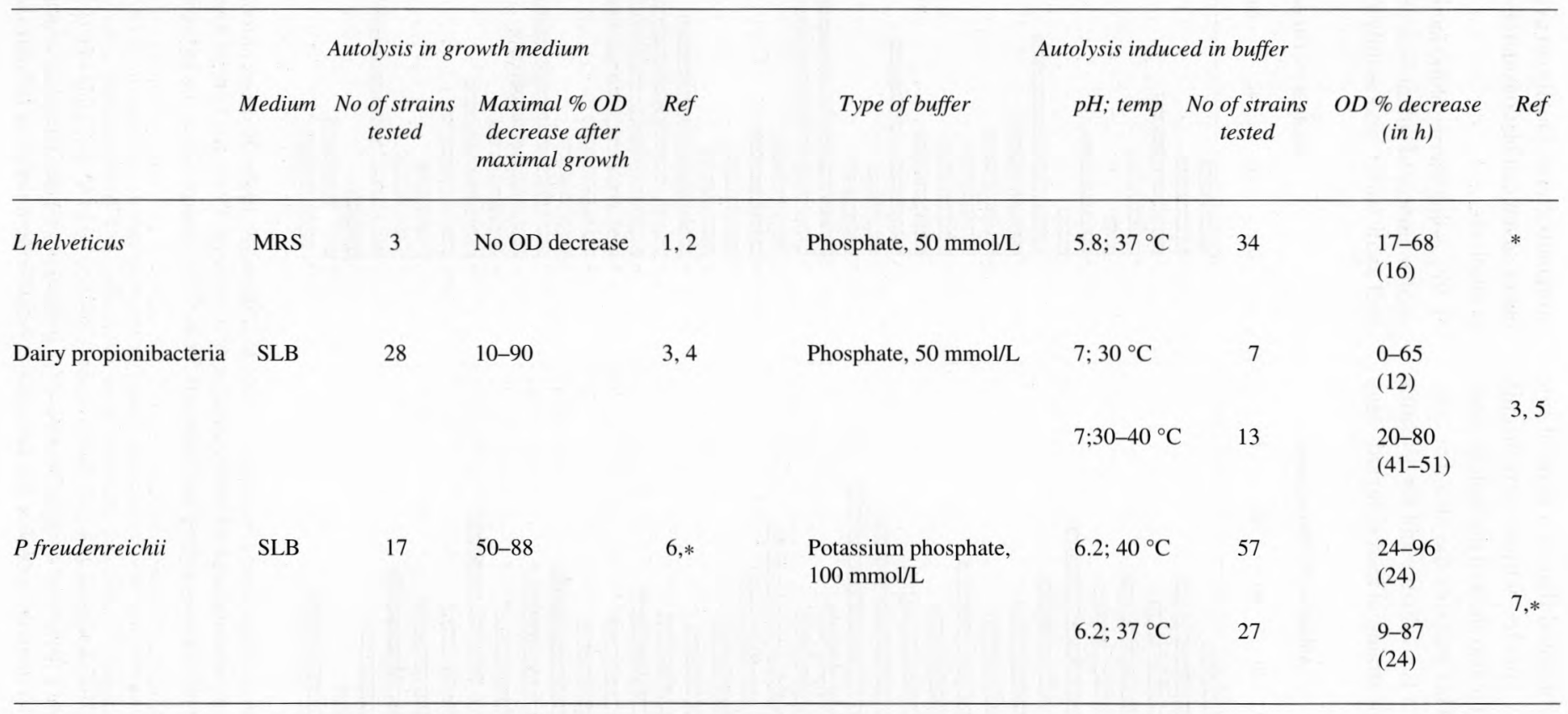


it could be highlighted that as a general rule strains of this species which were highly autolytic in buffer also showed the highest autolysis in broth. This supports the idea that comparison in buffer is a valuable tool for detecting the best autolytic strains, at least as regards dairy propionibacteria. Finally, in average one strain out of seven can be considered as highly prone to autolysis.

Regarding thermophilic lactobacilli, a much smaller number of strains was studied in broth as well as in buffer, and mainly for one species:
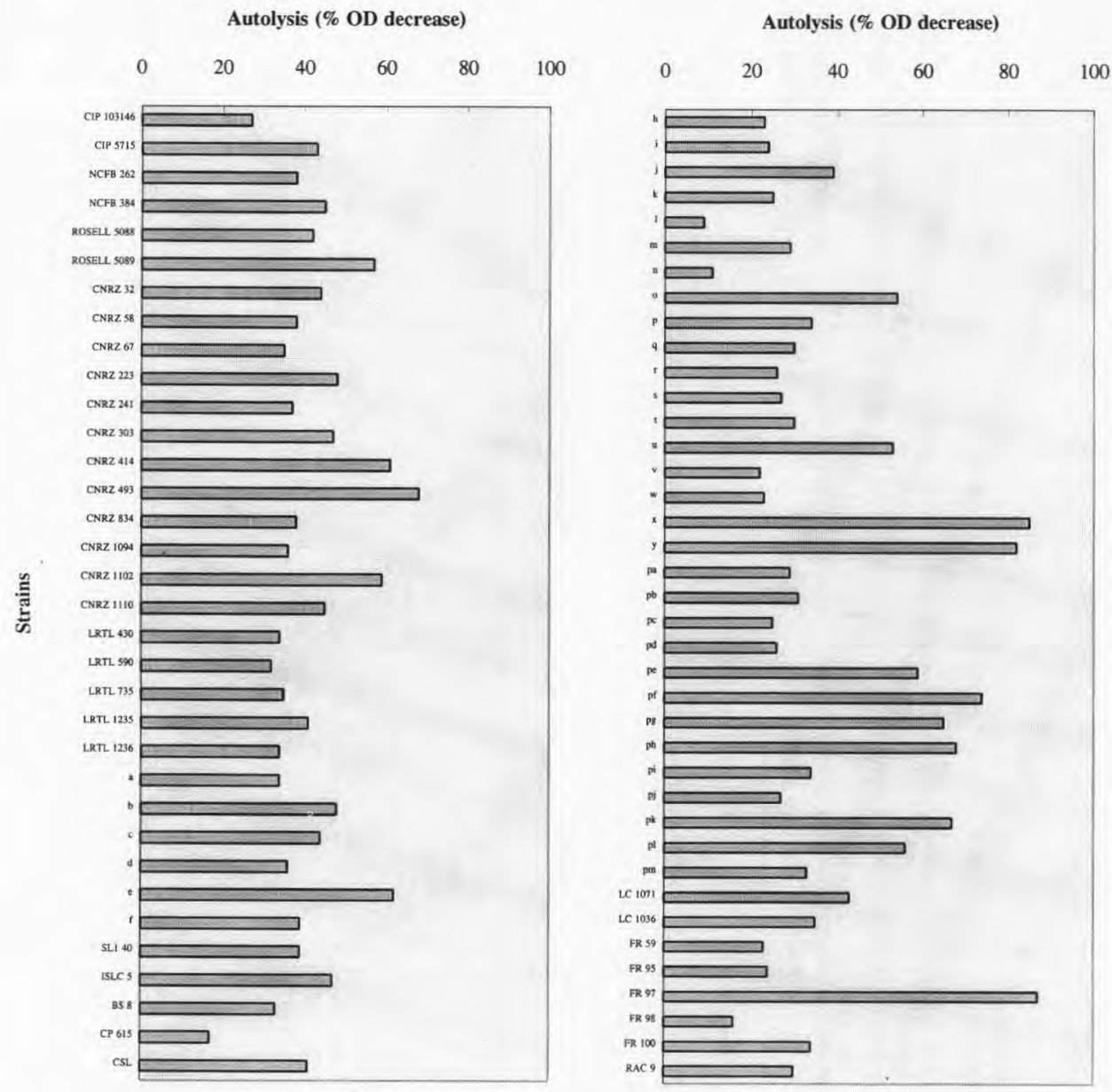

Fig 3. Autolytic strain-dependence (expressed as $\%$ of $\mathrm{OD}_{650}$ decrease). Right: 39 strains of $P$ freudenreichii after $24 \mathrm{~h}$ in $0.1 \mathrm{~mol} / \mathrm{L}$ potassium phosphate buffer, $\mathrm{pH} 6.2$ at $40^{\circ} \mathrm{C}$ (average $35 \% \pm 20$ ). Left: 34 strains of $L$ helveticus after $16 \mathrm{~h}$ in $0.1 \mathrm{~mol} / \mathrm{L}$ potassium phosphate buffer, $\mathrm{pH} 5.8$ at $37^{\circ} \mathrm{C}$ (average $42 \% \pm 10$ ). Industrial strains are indicated by letters.

Illustration du caractère souche-dépendant de l'autolyse (pourcentage de réduction de la $D O_{650}$, mesuré dans les conditions indiquées ci-dessous). À droite : pour 39 souches de $\mathrm{P}$ freudenreichii; autolyse mesurée après 24 heures en tampon phosphate de potassium $0,1 \mathrm{~mol} / \mathrm{L}$ à $\mathrm{pH} 6,2$ et à $40^{\circ} \mathrm{C}$ (moyenne: $35 \% \pm 20$ ). À gauche : pour 34 souches de L helveticus; autolyse mesurée après 16 heures en tampon phosphate de potassium $0,1 \mathrm{~mol} / \mathrm{L}$ à $\mathrm{pH} 5,8$ et à $37^{\circ} \mathrm{C}$ (moyenne: $42 \% \pm 10$ ). Les souches industrielles testées sont indiquées par des lettres. 
$L$ helveticus (table I). One of the most surprising facts is that no obvious $\mathrm{OD}_{650}$ reduction was observed after maximal growth in MRS broth (de Man et al, 1960) even after a very long period. But depending on the strain, the viability decreased relatively rapidly after maximal growth and a variable ability to form ghosts could be noted by phase contrast microscopy. Very interestingly, the cells could appear partially or completely empty, ie, autolysed, but their rod form was maintained (as illlustrated in fig 4); this can explain the absence of $\mathrm{OD}_{650}$ decrease. Thus, the autolytic process of $L$ helveticus in MRS broth is seemingly not as explosive as it was for $P$ freudenreichii, but more linked to a progressive leakage of cytoplasm through a residual cell wall structure. The most probable explanation is that the proteinaceous paracrystalline layer (S-layer) present in the cell walls of $L$ helveticus is not degraded, and helps to maintain a rod-shape appearance after hydrolysis of the peptidoglycan by the autolysins. Indeed, this S-layer is the outermost layer of the cell wall, and in $L$ helveticus it constitutes about $50 \%$ of the cell wall dry weight (Lortal et al, 1992).

When autolysis of $L$ helveticus was assayed in buffer, some $\mathrm{OD}_{650}$ reduction was noted, ie, from 17 to $68 \%$ (in $16 \mathrm{~h}$ ), depending on the strain. Very interestingly, Premi et al (1973) noted that the strains growing with a filamentous phenotype were the least autolytic in buffer. Nevertheless, even if some differences between $L$ helveticus strains were found, evidence is pro-

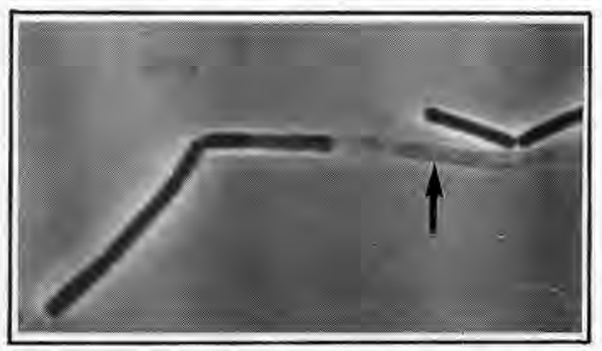

Fig 4. Ghost rods (arrow) observed during autolysis of $L$ helveticus in MRS medium.

Fantômes observés pendant l'autolyse de L helveticus en milieu MRS. vided by the histograms in figure 3 that the variation of $\mathrm{OD}_{650}$ decrease between strains was much lower for $L$ helveticus than for $P$ freudenreichii. This observation is clearly supported by the calculation of the average and standard deviation in each case (see legend to fig 3 ). Because of this, it was more difficult to assess which $L$ helveticus strains should be considered as more prone to autolysis. In fact, we now suspect that measurement of $\mathrm{OD}_{650}$ reduction in buffer as well as in broth is not the best approach to use, due to the tendency of $L$ helveticus to maintain a rather well-conserved rod shape during autolysis. In our opinion, it is more the ability to rapidly release intracellular compounds (DNA, enzymes, etc) that should be considered in comparing the autolytic activity of thermophilic lactobacilli, at least for S-layer-carrying species (Lortal, 1993).

In conclusion, autolytic strain-dependence has been clearly demonstrated in the literature for dairy propionibacteria, and less easily for $L$ helveticus, for which an improved screening method should be developed. Apart from unpublished work, we have no idea of the extent of strain variations in other thermophilic lactobacilli such as $L$ acidophilus and $L$ delbrueckii subsp bulgaricus. Regarding $L$ delbrueckii subsp lactis, even if a very limited number of strains has been tested, significant variations in $\mathrm{OD}_{650}$ reduction (in $0.1 \mathrm{~mol} / \mathrm{L}$ potassium phosphate buffer, $\mathrm{pH}$ 5.8 ) were observed ( 41 to $94 \%$ in $16 \mathrm{~h}$ ). Two strains out of seven were seemingly more prone to lysis (unpubl obs). Thus screening by the method of $\mathrm{OD}_{650}$ reduction in buffer could apparently be carried out successfully with a larger number of strains of this species; this is in accordance with our hypothesis, since its cell wall is to our knowledge devoid of an S-layer (Lortal, 1993; Boot, pers commun).

For all species in which some results exist regarding autolytic strain-dependence, there are two main questions to answer: i) the first regards fundamental research; why does one strain autolyse better than the others? Could it be related to a better enzymatic autolytic system, or to slight differences in the cell wall structure and com- 
position (percentage of peptidoglycan reticulation, presence of various amounts of teichoic acids, or other reasons), or is it just a consequence of a more general metabolic regulation, as for example the capacity to maintain an energized membrane, as evoked for $B$ subtilis (Joliffe et al, 1981; Kemper and Doyle, 1993)? ii) the second question is more pragmatic, and regards their role as starters: are the strains which are more prone to lysis under laboratory conditions (in broth or in buffer) also the more autolytic under technological conditions, and more precisely in cheeses? This is a key question in validating or not the procedures developed in vitro to detect autolytic strains, and to eventually add this criteria to the others traditionally used in the choice of a starter.

\section{CELL WALL HYDROLYSIS AND AUTOLYSIN SPECIFICITY}

Several autolysins of various specificity (amidase, glycosidase, peptidase) are often present together in the cell wall of a species, as has been described in several Gram( + ) species: Bacillus subtilis, Enterococcus pneumoniae, or Staphylococcus aureus (Schockman and Höltje, 1994).

Determination of the specificity, ie, the nature of the cleaved bonds in the peptidoglycan during autolysis, implies cell wall isolation of the species considered without denaturing the autolysins present inside. This step is generally carried out in the cold by mechanical disruption of whole cells (more often glass beads or French press), and successive washes of the cell walls obtained. These cell walls are then suspended in a buffer at a temperature, ionic strength, $\mathrm{pH}$ and composition optimal for the expression of the considered autolysins; this optimization must be achieved before determining the specificity (in general, the optimal parameters are very close to those defined for whole cell autolysis). The appearance of specific biochemical residues is followed in parallel to cell wall hydrolysis: i) the increase in reducing groups indicates the presence of a glycosidase; ii) the increase in free amino groups indicates the presence of an amidase or a peptidase (Ghuysen et al, 1966). If a glycosidase is detected, a reduction of the samples by sodium borohydride is necessary to generate and quantify muramicitol (in the case of an $\mathrm{N}$-acetylmuramidase) or glucosaminitol in the case of an $\mathrm{N}$-acetylglucosaminidase (Hara and Matsushima, 1966). To distinguish between amidase and peptidase, it is necessary to reveal the nature of the amino acid whose $\mathrm{NH}_{2}$ residue has been freed. For that purpose, this terminal amino acid is blocked by dinitrophenylation and identified after complete acid hydrolysis of the crude cell wall suspension at various times of hydrolysis.

As far as we know, the predominant specificity detected during cell wall hydrolysis of thermophilic lactobacilli was an $\mathrm{N}$-acetylmuramidase as has been described for $L$ acidophilus (Coyette and Ghuysen, 1970a; Coyette and Shockman, 1973), L helveticus (Lortal et al, 1991) and L fermentum (Neujahr and Logardt, 1973). Nevertheless, in this last species, evidence of the presence of an $\mathrm{N}$-acetyl-muramoyl$\mathrm{L}$-alanine amidase and a peptidase (cleaving the L-Ala-D-Glu bond) has also been provided (table II). To be certain that peptidase or amidase activities are not present in $L$ helveticus or $L$ acidophilus, more sensitive detection methods should be used such as, for example, radioactive labelled cell walls (with $\mathrm{L}-\left[{ }^{14} \mathrm{C}\right]$-alanine) (Margot et al, 1991). But the presence of S-layers could again be a limiting factor in the detection of amidasic and peptidasic activities for two reasons: i) this quantitatively predominant cell wall protein can generate an initial high level of free amino groups, then making the detection of a slight increase in these residues due to peptidoglycan hydrolysis difficult; ii) the fact that the $\mathrm{N}$-terminal sequence of the S-layerforming protein of $L$ acidophilus as well as $L$ helveticus starts by an alanine residue (Lortal et al, 1992; Boot et al, 1993) makes the use of the appearance of DNP-Ala (radioactively labelled or not) during cell wall hydrolysis, to detect an eventual $\mathrm{N}$-acetyl-muramoyl-L-Ala-amidase, rather problematic. For all these reasons, we 
Table II. The autolytic system of thermophilic lactobacilli and propionibacteria.

Système autolytique des lactobacilles thermophiles et des bactéries propioniques.

\begin{tabular}{|c|c|c|c|c|c|}
\hline \multirow[t]{2}{*}{ Species } & \multirow[t]{2}{*}{ Autolysin specificity } & \multicolumn{3}{|c|}{ Renaturating SDS-PAGE } & \multirow[b]{2}{*}{$\operatorname{Ref}$} \\
\hline & & Substrate & No of major lytic bands & Apparent $M W(k D a)$ & \\
\hline Lhelveticus & $N$-acetylmuramidase & $\begin{array}{l}\text { M luteus } \\
\text { L helveticus } \\
\quad \text { Cells } \\
\quad \text { SDS cell walls }\end{array}$ & $\begin{array}{l}2 \\
2 \\
3\end{array}$ & $\begin{array}{c}30 / 42.4 \\
30 / 42.4 \\
30 / 37.5 / 42.4\end{array}$ & 1,2 \\
\hline L acidophilus & $N$-Acetylmuramidase & $M$ luteus & 4 & $27 / 28 / 30 / 43$ & $3, *$ \\
\hline L delbruekii subsp lactis & ND & M luteus & 2 & $31 / 44$ & $*$ \\
\hline$L$ fermentum & $\begin{array}{l}N \text {-Acetylmuramidase } \\
\text { amidase } \\
\text { endopeptidase }\end{array}$ & $M$ luteus cells & 2 & $56 / 89$ & $4, *$ \\
\hline$P$ freudenreichii & $N$-Acetylglucosaminidase & $\begin{array}{l}\text { M luteus } \\
\text { P freudenreichii } \\
\text { Cells } \\
\text { Cell walls }\end{array}$ & $\begin{array}{l}0 \\
8 \\
8\end{array}$ & $\begin{array}{l}34 / 81-121 \\
34 / 81-121\end{array}$ & $5, *$ \\
\hline & $\begin{array}{l}\text { Glycosidase and } \\
\text { amidase or endopeptidase }\end{array}$ & & $1-8$ & $20-150$ & 6 \\
\hline
\end{tabular}

[1] Lortal et al, 1992; [2] Valence and Lortal, 1995; [3] Coyette and Shockman, 1973; [4] Neujhar and Logardt, 1973; [5] Lèmée et al, 1995; [6] Østlie et al, 1995c; * unpublished data; ND: not determined. 
consider that the complete description of the peptidoglycan hydrolase specificities possibly present in thermophilic lactobacilli implies extraction of the S-layer protein, when they are present, before investigating the presence of amidase or peptidase activity during cell wall hydrolysis.

For $L$ delbrueckii subsp lactis and $L$ delbrueckii subsp bulgaricus, as far as we know, cell wall hydrolysis has never been described and, a fortiori, the nature of cleaved bonds in the peptidoglycan.

Regarding dairy propionibacteria, a very active $\mathrm{N}$-acetylglucosaminidase was detected during the cell wall hydrolysis of $P$ freudenreichii CNRZ 725 (Lemée et al, 1994b). The optimal pH of this $\mathrm{N}$-acetylglucosaminidase was shown to be 5.8 , and this value is very close to the $\mathrm{pH}$ of Swiss cheese curd at the beginning of warm room ripening ( $\mathrm{pH} 5.5$ to 5.7). Moreover, even if the optimal temperature of this enzyme is high $\left(40{ }^{\circ} \mathrm{C}\right)$, it was still active at $15-24^{\circ} \mathrm{C}$, indicating that the temperature of the ripening room is also compatible with its expression. On the other hand, even if clearly predominant, this $\mathrm{N}$-acetylglucosaminidase could be associated with other autolysins. Indeed, it has been noted that the extent of cell wall hydrolysis continues to increase although the evolution of the reducing power has stopped (after $2 \mathrm{~h}$ of hydrolysis). This may indicate the presence of minor amidasic or peptidasic activities which would be able to further degrade soluble peptidoglycan fragments. This possibility has been further supported by other authors, who have indicated an increase in free amino residues during cell wall hydrolysis (

\section{CHARACTERIZATION OF AUTOLYSINS BY RENATURING SDS-PAGE (ZYMOGRAM)}

In 1988-1989, a very powerful method for visualizing lytic activities was described in the literature (Potvin et al, 1988; Leclerc and Asselin, 1989). Briefly, a usual SDS-PAGE is carried out, except that a substrate is incorporated into the gel when making it (whole cells or cell walls of the considered species or whole cells of Micrococcus luteus). After migration, a renaturing step is carried out by gently shaking the gel in a buffer containing 0.1 to $1 \%$ of Triton $\mathrm{X}-100$. Usually, after a few hours the proteins which possess lytic activity generate clear bands in the opaque background. In addition to a very high sensitivity, this method has the major advantage of allowing the estimation of the apparent molecular weight of the lytic activities detected. Since it has been described, the socalled 'renaturing SDS-PAGE' has been applied to characterize the autolysins of numerous species including $B$ subtilis, $S$ aureus, $E$ coli or Pseudomonas (Sugai et al, 1990; Foster, 1992; Bernadsky et al, 1994; Tobin et al, 1994; Watt and Clarke, 1994; Rashid et al, 1995).

Regarding the species $L$ helveticus, the renaturing SDS-PAGE of cellular SDS-extracts revealed the presence of at least two lytic bands of about 30 and $42 \mathrm{kDa}$ (using $M$ luteus or whole cells of $L$ helveticus as substrate) (table II; fig 5). At this stage it is difficult to judge whether the two lytic area correspond to distinct enzymes, or if the $30 \mathrm{kDa}$ bands are processed forms of the $42 \mathrm{kDa}$ enzyme. To our minds what should be considered as obviously different is the 37.5 $\mathrm{kDa}$ additional lytic activity, which was visualized only when purified cell walls of $L$ helveticus were included in the gel instead of whole cells (Valence and Lortal, 1995). According to Shockman and Höltje's definition (1994), this $37.5 \mathrm{kDa}$ enzyme should be considered as a peptidoglycan hydrolase and not as a true autolysin, since it does not seem able to generate the lysis of whole cells. Whether this last activity participates or not in the autolytic process remains to be determined. Currently, the purification of the $42 \mathrm{kDa}$, which was started previously (Valence and Lortal, 1995), is being further investigated in our laboratory. Finally, it may be interesting to point out that the species $L$ acidophilus and $L$ delbrueckii subsp lactis showed lytic activities with similar apparent molecular weights when compared to $L$ helveticus (unpubl obs; fig 5 ). 
(a)

1

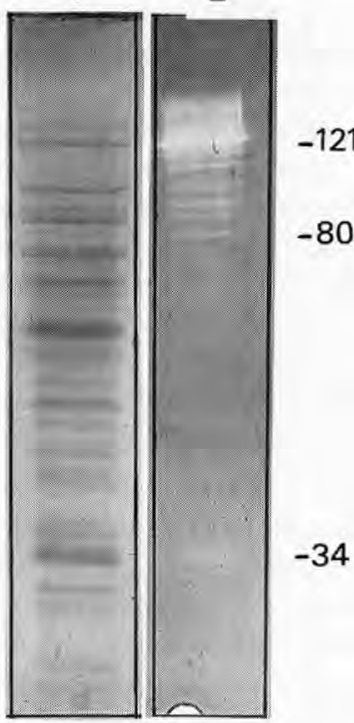

(b)

3

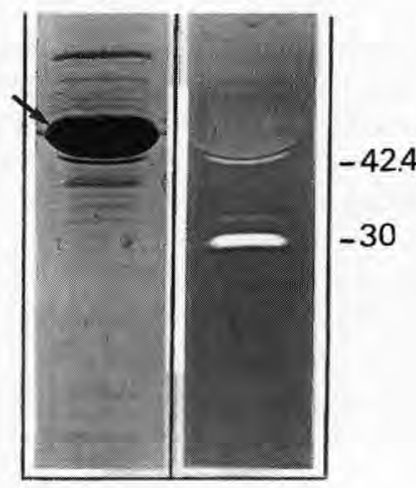

(c)

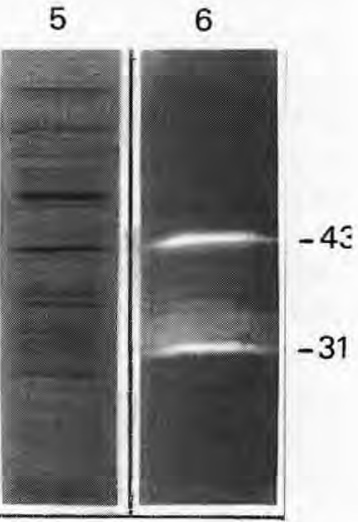

Fig 5. Protein profile (lane 1) and lytic enzymes profile (lane 2) of partially purified extract of $P$ freudenreichii autolysins. The lytic activities were revealed by using gel containing $2 \%(\mathrm{wt} / \mathrm{vol})$ of $P$ freudenreichii autoclaved cells (a). Protein profile (lanes 3 and 5) and lytic enzyme profiles (lane 4 and 6) of cellular SDS-extract of $L$ helveticus (b) and $L$ delbrueckii subsp lactis (c). The lytic activities were revealed by using gels containing $0.2 \%$ ( $\mathrm{wt} / \mathrm{vol}$ ) lyophilized cells of $M$ luteus. The predominant S-layer forming protein of $L$ helveticus is indicated by the arrow. The apparent molecular masses (in kilodaltons) of the lytic bands are indicated on the right.

Profil protéique (puits 1) et profil des activités lytiques (puits 2) d'un extrait d'autolysines partiellement purifiées de $\mathrm{P}$ freudenreichii. Les activités lytiques sont révélées par la présence dans le gel de cellules autoclavées de P freudenreichii $(2 \% p / v)(a)$. Profil protéique (puits 3 et 5 ) et profil des activités lytiques (puits 4 et 6 ) d'un extrait $S D S$ de cellules entières de $\mathrm{L}$ helveticus $(\boldsymbol{b})$ et $\mathrm{L}$ delbrueckii subsp lactis $(\boldsymbol{c})$. Les activités lytiques sont révélées par la présence dans le gel de cellules lyophilisées de $\mathrm{M}$ luteus $(0,2 \% \mathrm{p} / \mathrm{v})$. La protéine prédominante correspondant à la $S$-layer de $\mathrm{L}$ helveticus est indiquée par une flèche. Les masses moléculaires apparentes $(k D a)$ des activités lytiques détectées sont indiquées sur la droite des profils.

Concerning $P$ freudenreichii, the lytic activities contained in a cellular SDS- or LiCl-extract can only be visualized by including whole cells or cell walls of $P$ freudenreichii in the gel. $M$ luteus is seemingly not a convenient substrate. In addition, the $\mathrm{pH}$ and nature of the renaturing buffer described in the literature $(50 \mathrm{mmol} / \mathrm{L}$ Tris- $\mathrm{HCl}, \mathrm{pH} 8.0,1 \%$ Triton X-100) did not lead to the determination of propionibacteria lytic activities. After an optimization step which is described in Lemée et al (1995), several lytic bands were detected (fig 5). In addition, it was interesting to note that the revelation of all these lytic activities can be made by incubating the gel directly in Emmental juice (obtained by pressing a piece of cheese; Salvat-Brunaud et 
al, 1995). Again, it was not possible to assess how many lytic enzymes were obviously different, and which one corresponded to the major $\mathrm{N}$-acetylglucosaminidase involved in the autolysis of that species. Moreover, several attempts to purify these activities, and in particular the 121 kDa enzyme, were unsuccessful (Lemée et al, 1995). Other dairy propionibacteria species ( $P$ jensenii, $P$ acidipropionici, and $P$ thoenii) also showed several lytic bands which were all different from those of $P$ freudenreichii. In addition, it should be noted that the lytic activities of these three species can be revealed by including whole cells of $P$ jensenii in the gel (unpubl obs), and that the profile differs greatly from that of $P$ freudenreichii.

\section{EXTRACTION AND PURIFICATION OF AUTOLYSINS}

As the autolysins are cell wall located and noncovalently bound to other cell wall components, several attempts to extract them from isolated cell walls or directly from cells have been described in the literature (Rogers et al, 1980, 1984; Shockman and Höltje, 1994). On the other hand, the autolysins frequently have the property to liberate themselves during cell wall hydrolysis in buffer; the supernatant harvested after several hours of cell wall hydrolysis may often constitute an interesting crude extract of autolysins. Nevertheless, this second approach could be time-consuming because the isolation of cell walls is required in this case. Moreover, the quantity of autolysins in cell walls is generally very low; this constitutes an evident limitation in purifying them.

Regarding thermophilic lactobacilli, Coyette and Shockman (1973) have submitted cell walls of $L$ acidophilus to several extraction procedures: $\mathrm{LiCl}$ ( 1 to $5 \mathrm{~mol} / \mathrm{L}$ ) or $0.1 \mathrm{~mol} / \mathrm{L} \mathrm{NaOH}$ in the presence of bovine serum albumin, both in the cold $\left(4^{\circ} \mathrm{C}\right)$. These two treatments led to a low residual activity in cell walls after extraction, but the lytic activity was only recovered in the supernatant of the $\mathrm{NaOH}$ procedure, providing it was rapidly neutralized. Neujahr and Logardt (1973) observed a spontaneous release in autolytic activity during hydrolysis of $L \mathrm{fer}$ mentum cell walls. Such a release was also observed by Premi et al (1973) for $L$ helveticus. Moreover, these authors observed that the crude extract of autolysins has an unchaining effect toward strains forming long chains. More recently, a $1 \mathrm{~mol} / \mathrm{L}$ lithium chloride solution was successfully used to extract the autolysins from isolated cell walls as well as from whole cells of $L$ helveticus. The extracted autolysins of this species have in addition been partially purified by selective precipitation and gel filtration chromatography (20-fold increase in specific activity) (Valence and Lortal, 1995).

The autolysins of $P$ freudenreichii can be extracted from whole cells by SDS or $\mathrm{LiCl}$ treatment. They are also liberated during cell wall hydrolysis; unfortunately, all attempts to purify them from this crude extract have been unsuccessful, seemingly because of its very high polysaccharide content (Lemée et al, 1995).

Thus, up to date there is no autolysin of lactobacilli or propionibacteria which has been purified to homogeneity. The method of renaturing SDS-PAGE described above, which allows the lytic enzymes to be easily followed (number and apparent molecular weights) during all steps of a purification scheme will certainly be of considerable help in future purification attempts.

\section{FUTURE PROSPECTS}

This review led to several final comments. Even if some indications exist in the literature on the autolysis in cheeses of thermophilic lactobacilli and dairy propionibacteria, in our opinion this remains to be definitively proved. This is particularly true for the effect of such an autolysis on the proteolysis of cheeses in which they are the principal starters. On the other hand, knowledge regarding the autolysins of these species has increased significantly over the last few years, at least at the biochemical level (conditions of expression, specificity, apparent molec- 
ular weight; partial purifications); amongst all lactobacilli and propionibacteria, $L$ helveticus and $P$ freudenreichit in particular are the two best-characterized species regarding autolysis. A complete purification of some of these autolysins, as well as a genetic approach, would now be required in order to interpret some of the conflicting data, as for example the presence of several lytic bands (by renaturing SDS-PAGE) parallel to only one enzymatic specificity detected during cell wall hydrolysis.

On the other hand, the autolytic strain-dependence which has been well described in buffered solutions for all these species should now be validated under technological conditions. This is of great importance in assessing whether the autolytic activity of dairy thermophilic lactobacilli and/or propionibacteria is a new criterion to take into consideration in starter selection. From a more general viewpoint, we consider that the understanding of this strain dependence at a molecular level may allow a better overall view of the regulation of this fascinating suicide' phenomenon.

\section{ACKNOWLEDGMENTS}

We thank our friend J Davies for his rapid revision of the English text. We would like to thank E Roussel for allowing us to cite some unpublished data, which were obtained thanks to the financial support of Standa-Industrie. Last but not least, the Lytic Club is greatly indebted to JL Maubois and J Van Heijenoort for their continued support and interest in this work.

\section{REFERENCES}

Accolas JP, Veaux M, Vassal L, Mocquot G (1978) Evolution de la flore lactique thermophile au cours du pressage des fomages à pâte cuite. Lait 58 . 573-574

Bernadsky G, Beveridge TJ, Clarke A (1994) Analysis of the sodium dodecyl sulfate-stable peptidoglycan autolysins of select gram-negative pathogens by using renaturing polyacrylamide gel electrophoresis. J Bacteriol 176, 5225-5232

Bie R, Sjöström G (1975a) Autolytic properties of some lactic acid bacteria used in cheese production. I. Material and methods. Milchwissenschaft 30, 653-657

Bie R, Sjöström G (1975b) Autolytic properties of some lactic acid bacteria used in cheese production. II. Experiments with fluid substrates and cheese. Milchwissenschaft 30, 739-747

Boot HJ, Kolen CPAM, van Noort J, Pouwels PH (1993) S-layer protein of Lactobacillus acidophilus ATCC 4356: purification, expression in Escherichia coli, and nucleotide sequence of the corresponding gene. J Bacteriol 175, 6089-6096

Bottazzi V (1993) Aspects of lactic acid bacteria biology. I. Growth and lysis of Lactobacillus cells in cheese. In: Biotechnology and Molecular Biology of Lactic Acid Bacteria for the Improvement of Foods and Feeds Quality (Zamorani A, Manachini PL, Botazzi V, Coppola S, eds) Instituto Poligrafito e Zeca Dello Stato, Rome

Bouton Y, Guyot P, Dasen A, Grappin R (1993) Activité protéolytique de souches de lactobacilles thermophiles isolées de levains et de Comté. I. Validation sur minifromages des techniques de laboratoire. Lait 73, 265-279

Bouton Y, Guyot P, Dasen A, Grappin R (1994) Activité protéolytique de souches de lactobacilles thermophiles isolées de levains et de Comté. II. Applications en sites industriels. Lait 74, 33-46

Buist G, Kok J, Leenhouts KI, Dabrowska M, Venema G, Haandrikman AJ (1995) Molecular cloning and nucleotide sequence of the gene encoding the major peptidoglycan hydrolase of Lactococcus lactis, a muramidase needed for cell separation. J Bacteriol 177, 1554-1563

Chapot-Chartier MP (1996) Les autolysines des bactéries lactiques. Lait 76, 91-109

Chapot-Chartier MP, Deniel C, Rousseau M, Vassal L. Gripon JC (1994) Autolysis of two different strains of Lactococcus lactis during cheese ripening. Int Dairy $J$ 4, 251-269

Coyette J, Ghuysen JM (1970a) Structure of the walls of Lactobacillus acidophilus strain 63 AM Gasser. Biochemistry 9, 2935-2943

Coyette J, Ghuysen JM (1970b) Wall autolysin of Lactobacillus acidophilus strain 63 AM Gasser. Biochemistry 9, 2952-2955

Coyette J, Shockman GD (1973) Some properties of the autolytic $\mathrm{N}$-acetylmuramidase of Lactobacillus acidophilus. I Bacteriol 114, 34-41 
Crow VL, Coolbear T, Holland R, Pritchard GG, Martley FG (1993) Starters as finishers: starter properties relevant to cheese ripening. Int Dairy $J 3,423-460$

Crow VL, Coolbear T, Gopal PK, Martley FG, Mc Kay LL, Riepe H (1995a) The role of autolysis of lactic acid bacteria in the ripening of cheese. Int Dairy J 5, 855-875

Crow VL, Martley FG, Coolbear T, Roundhill SJ (1995b) The influence of phage-assisted lysis of Lactococcus lactis sp lactis ML 8 on Cheddar cheese ripening. Int Dairy J 5, 451-472

de Man JC, Rogosa M, Sharpe E (1960) A medium for the cultivation of lactobacilli. J Appl Bacteriol $23,130-135$

Dupuis (1994) Activités protéolytiques et lipolytiques des bactéries propioniques laitières. Thesis ENSA. Rennes, France

Dupuis C, Boyaval P (1993) Esterase activity of dairy Propionibacterium. Lait 73, 345-356

Dupuis C, Corre C, Boyaval P (1993) Lipase and esterase activities of Propionibacterium freudenreichii subsp freudenreichii. Appl Environ Microbiol 159, 4004-4009

El Soda M (1993) The role of lactic acid bacteria in accelerated cheese ripening. FEMS Microbiol Rev $12,239-252$

El Soda M, El Wahab HA, Ezzat N, Desmazeaud MJ, Ismail A (1986) The esterolytic and lipolytic activities of the lactobacilli. II. Detection of the esterase system of Lactobacillus helveticus, Lactobacillus bulgaricus, Lactobacillus lactis and Lactobacillus acidophilus, Lait 66, 431-443

Fernandez Murga ML, Ruiz Holgado AP, de Valdez GF (1994) Influence of the $\mathrm{pH}$ on the autolytic activity of Lactobacillus acidophilus. Microbiol Aliments Nutr 12, 423-428

Fernandez Murga ML, Ruiz Holgado AP, de Valdez GF (1995) Influence of the incubation temperature on the autolytic activity of Lactobacillus acidophilus. J Appl Bacteriol 78, 426-429

Forsberg C, Rogers HJ (1971) Autolytic enzymes in growth of bacteria. Nature 229, 272-273

Foster SJ (1992) Analysis of the autolysins of Bacillus subrilis 168 during vegetative growth and differentiation by using renaturing polyacrylamide gel electrophoresis. J Bacteriol 174, 464-470

Ghuysen JM, Tipper DJ, Strominger JL (1966) Enzymes that degrade bacterial cell walls. Methods Enzymol 8, 694-696
Hara S. Matsushima Y (1966) Studies on the aminohexoses. XII. Crystalline muramicitol and its use in a study of the lysozyme action on the cell walls of Micrococcus lysodeikticus. Bull Soc Chem Japan 39, 1826

Johnson JAC, Etzel MR, Chen CM, Johnson ME (1995) Accelerated ripening of reduced-fat Cheddar using four attenuated Lactobacillus helveticus CNRZ 32 adjuncts. J Dairy Sci 78, 769-776

Joliffe LK, Doyle RJ, Streips UN (1981) The energized membrane and cellular autolysis in Bacillus subtilis. Cell 25, 753-763

Kemper MA, Doyle RJ (1993) The cell wall of Bacillus subtilis is protonated during growth. In: Bacterial Growth and Lysis (de Pedro MA et al, eds) Plenum Press, New York, 245-252

Klein J, Schmidt JR, Plapp R (1994) Cloning heterologous expression, and sequencing a novel proline iminopeptidase gene, pepl, from Lactobacillus delbrueckii subsp lactis DSM 7290. Microbiology 140, 1133-1139

Lambrechts C (1993) Étude et caractérisation des systèmes estérasiques de bactéries coryneformes. Thesis, ENSA, Montpellier, France

Langsrud T (1974) Proline production in propionibacteria, PhD Thesis, Iowa State Univ, IA

Langsrud T, Reinbold GW (1973) Flavour development and microbiology of Swiss cheese - a review. III. Ripening and flavour production. J Milk Food Technol 36, 593-609

Langsrud T, Reinbold GW, Hammond EG (1977) Proline production by Propionibacterium freudenreichii P59. J Dairy Sci 60, 16-23

Langsrud T, Reinbold GW, Hammond EG (1978) Free proline production by strains of Propionibacteria. J Dairy Sci 61, 303-308

Langsrud T, Landaas A, Castberg HB (1987) Autolytic properties of different strains of group $\mathrm{N}$ streptococci. Milchwissenshaft 42, 556-560

Langsrud T, Sorhaug T, Vegarud GE (1995) Protein degradation and amino acid metabolism by propionibacteria, Lait $75,325-330$

Law BA, Sharpe ME, Reiter B (1974) The release of intracellular dipeptidase from starter streptococci during Cheddar cheese ripening. I Dairy Res 41, $137-146$

Leclerc D, Asselin A (1989) Detection of bacterial cell wall hydrolases after denaturing polyacrylamide gel electrophoresis. Can J Microbiol 35 , 749-753 
Leduc M, van Heijenoort J (1980) Autolysis of Escherichia coli. J Bacteriol 142, 52-59

Leduc M, Kasra R, van Heijenoort J (1982) Induction and control of the autolytic system of Escherichia coli. I Bacteriol 152, 26-34

Lemée R, Lortal S, van Heijenoort J (1995) Autolysis of dairy propionibacteria: isolation and renaturing gel electrophoresis of the autolysins of Propionibacterium freudenreichii CNRZ 725. Lait 75 . 345-365

Lemée R, Rouault A, Guézenec S, Lortal S (1994a) Autolysis of 57 strains of dairy propionibacteria. Lait 74, 241-251

Lemée R, Lortal S, Cesselin B, van Heijenoort J (1994b) Involvement of an $N$-acetylglucosaminidase in autolysis of Propionibacterium freudenreichii CNRZ 725. Appl Environ Microbiol $60,4351-4358$

Lortal S (1993) Crystalline surface-layers of the genus Lactobacillus. In: Advances in Paracrystalline Surface Layers (Beveridge TJ, Koval SF, eds) Plenum Press, New York

Lortal S, Boyaval P, van Heijenoort J (1989) Influence de plusieurs facteurs sur l'autolyse de $\mathrm{Lac}$ tobacillus helveticus CNRZ 414. Lait 69, 223-231

Lortal S, Rousseau M, Boyaval P. van Heijenoort J (1991) Cell wall and autolytic system of Lactobacillus helveticus ATCC12046, J Gen Microbiol 137, 549-559

Lortal S, van Heijenoort J, Gruber K, Sleytr UB (1992) S-layer of L helveticus ATCC 12046: isolation, chemical characterization and re-formation after extraction with lithium chloride. J Gen Microbiol $138,611-618$

Margot P, Roten CAH, Karamata D (1991) N-acetylmuramoyl-L-alanine amidase assay based on specific radioactive labeling of muropeptide L-alanine: quantification of the enzyme activity in the autolysin-deficient Bacillus subtilis 168, fla D strain. Anal Biochem 198, 15-18

Monnet V, Chapot-Chartier MP, Gripon JC (1993) Les peptidases des lactocoques. Lait 73, 97-108

Neujahr HY, Logardt IM (1973) Autolytic enzyme from Lactobacillus fermenti. Biochemistry 12 , 2578-2583

Nowakowski CM, Bhowmik TK, Steele JL (1993) Cloning of peptidase genes from Lactobacillus helveticus CNRZ32. Appl Microbiol Biotechnol 39. 204-210

Ohmiya K. Sato Y (1970) Studies on the proteolytic action of dairy lactic acid bacteria. Part X. Auto- lysis of lactic acid bacteria cells in aseptic rennet curd. Agric Biol Chem 34, 457-463

Ohmiya K, Sato Y (1975) Promotion of autolysis in lactobacilli. Agric Biol Chem 39, 585-589

Østlie HM, Floberghagen V, Reinbold G, Hammond EG, Vegarud G, Langsrud T (1995a) Autolysis of dairy propionibacteria: growth studies, peptidase activities and proline production. J Dairy Sci 78, 1224-1237

Østlie HM, Vegarud G, Langsrud T (1995b) Autolysis of dairy propionibacteria in buffer systems. I Dairy Sci 78, 2315-2321

Østlie HM, Langsrud T, Andersen K, Vegarud G (1995e) Identification of autolytic enzymes from propionibacteria. In: Abstr, Ist Int Symp Dairy Propionibacteria, Rennes, France (poster)

Potvin C, Leclerc D, Tremblay G, Asselin A, Bellemare G (1988) Cloning, sequencing and expression of a Bacillus bacteriolytic enzyme in Escherichia coli. Mol Gen Genet 214, 241-248

Premi L, Vescovo M, Bottazzi V (1973) Wall autolysin of Lactobacillus helveticus. Ann Microbiol 23. 83-94

Pritchard GG, Coolbear T (1993) The physiology and biochemistry of the proteolytic system in lactic acid bacteria. FEMS Microbiol Rev 12, 179-206

Prost F, Chamba JF (1994) Effect of aminopeptidase activity of thermophilic lactobacilli on Emmental cheese characteristics. I Dairy Sei 77, 24-33

Rashid MH, Sato N, Sekigushi J (1995) Analysis of the minor autolysin of Bacillus subtilis during vegetative growth by zymography. FEMS Microbiol Lett 132, 131-137

Richoux R, Kerjean JR (1995) Caractérisation technologique de souches pures de bactéries propioniques : test en minifabrication de fromage à pâte cuite, Lait 75, 45-59

Rogers HJ, Perkins HR, Ward JB (1980) The bacterial autolysins. In: Microbial Cell Walls and Membranes (Rogers HJ, Perkins HR, Ward JB, eds) Chapman and Hall, London, 437-460

Rogers HJ, Taylor C, Rayter S, Ward JB (1984) Purification and properties of autolytic endo- $\beta-N$-acetylglucosaminidase and the $N$-acetylmuramyl-L-alanine amidase from Bacillus subtilis strain 168. J Gen Microbiol 130, 2395-2402

Salvat-Brunaud D, Maubois JL, Le Great Y, Piot M, Corre C, Thierry A (1995) Extraction et analyse de la phase aqueuse de l'Emmental à quatre stades d'affinage. Lait 75, 239-249 
Sasaki M, Boosman BW, Tan PST (1995) Comparison of proteolytic activities in various lactobacilli. J Dairy Res 62, 601-610

Shockman GD (1965) Symposium on the fine structure and replication of bacteria and their parts. IV. Unbalanced cell wall synthesis: autolysis and cell wall thickening. Bacteriol Rev 29, 345-358

Shockman GD, Höltje JV (1994) Microbial peptidoglycan (murein) hydrolases: comprehensive biochemistry. In: Bacterial Cell Wall (Ghuysen JM, Hakenbeck R, eds) Elsevier, London

Sugai N, Akiyama T, Komatsuzawa H, Miyake Y, Suginaka H (1990) Characterization of sodium dodecyl sulfate-stable Staphylococcus aureus bacteriolytic enzymes by polyacrylamide gel electrophoresis. J Bacteriol 172, 6494-6498

Tan PST, Poolman B, Konings WN (1993) Proteolytic enzymes of Lactococcus lactis. J Dairy Res 60, 269-286

Tobin PJ, Mani, Jayaswal RK (1994) Effect of physiological conditions on the autolysis of Staphylococcus aureus strains. Antonie Leeuwenhoek 65 , 71-78

Torriani S, Vescovo M, Scolari G (1994) An overview on Lactobacillus helveticus. Ann Microbiol Enzymol 44, 163-191

Umanskii MS, Borovkova YA (1979) Lipolytic activity of lactic acid and propionic acid bacteria. Molochn Promst 6, 20-23

Umanskii MS, Borovkova YA, Guseva NM, Klimovskii II, Gudkov AV (1974) Effect of bac- terial starters with different levels of glycerol ester hydrolase capacity on lipolytic processes and quality of Sovietskii cheese. In: Intensifikatsiya Proizvodstva i Uluchshenie Kachestva Natural' nykh Syrov. Barnaul, USRR, 379-382

Valence F, Lortal S. (1995) Zymogram and preliminary characterization of Lactobacillus helveticus autolysins. Appl Environ Microbiol 61, 3391-3399

Varmanen P, Vesanto E, Steele JL, Palva A (1994) Characterization and expression of the pepN encoding a general aminopeptidase from Lactobacillus helveticus. FEMS Microbiol Lett 124, 315-320

Watt SR, Clarke AJ (1994) Initial characterization of two extracellular autolysins from Pseudomonas aeruginosa PAO1. J Bacteriol 176, 4784-4789

Wilkinson MG (1993) Acceleration of cheese ripening. In: Cheese: Chemistry, Physics and Microbiology (Fox PF, ed) Chapman and Hall, London, 523-555

Wilkinson MG, Guinee TP, O'Callaghan DM, Fox PF (1994a) Autolysis and proteolysis in different strains of starter bacteria during Cheddar cheese ripening. J Dairy Res 61, 249-262

Wilkinson MG, Guinee TP, Fox PF (1994b) Factors which may influence the determination of autolysin starter bacteria during Cheddar cheese ripening. Int Dairy J 4, 141-160

Yüksel GU, Steele JL (1996) DNA sequence analysis, expression, distribution, and physiological role of the Xaa-prolyldipeptidyl aminopeptidase gene from Lactobacillus helveticus CNRZ32. Appl Microbiol Biotechnol 44, 766-773 